\section{Field Evaluation of 64 Apple Rootstocks for Orchard Performance and Fire Blight Resistance}

\author{
Nicole L. Russo \\ Department of Plant Pathology, Cornell University, New York Agricultural \\ Experiment Station, 630 West North Street, Geneva, NY 14456
}

Terence L. Robinson ${ }^{1}$

Department of Horticultural Sciences, Cornell University, New York State Agricultural Experiment Station, 630 West North Street, Geneva, NY 14456

\section{Gennaro Fazio}

United States Department of Agriculture, Agricultural Research Service, Plant Genetic Resources Unit, Cornell University, Geneva, NY 14456 and Department of Horticultural Sciences, Cornell University, New York State Agricultural Station, 630 West North Street, Geneva, NY 14456

\author{
Herb S. Aldwinckle ${ }^{1}$ \\ Department of Plant Pathology, Cornell University, New York Agricultural \\ Experiment Station, 630 West North Street, Barton Lab, Geneva, NY 14456
}

Additional index words. Malus $\times$ domestica, dwarfing, yield efficiency, fruit size, Erwinia amylovora

\begin{abstract}
In 2002, apple rootstock trials using three scion cultivars were established at Geneva, NY, to evaluate 64 apple (Malus $\times$ domestica Borkh.) rootstocks for horticultural performance and fire blight resistance. Field trials compared several elite Geneva ${ }^{\circledR}$ apple rootstocks, which were bred for tolerance to fire blight and Phytophthora root rot, to both commercial standards and elite rootstock clones from around the world. Three rootstocks performed well with all scion cultivars: 'B.9', 'Geneva ${ }^{\circledR} 935$ ', and 'Geneva ${ }^{\circledR} 41$ '. All three rootstocks were similar in size to 'M.9' clones but with elevated yield efficiency and superior resistance to fire blight. 'Geneva ${ }^{\circledR} 11$ ' also performed very well with 'Golden Delicious' and 'Honeycrisp' with regard to yield efficiency and disease resistance. Resistant rootstocks greatly enhanced the survival of young trees, particularly with the susceptible scion cultivars 'Gala' and 'Honeycrisp'. Results demonstrate the ability of new rootstock clones to perform better than current commercial standards, reducing financial risk to producers while promoting orchard health with enhanced disease resistance.
\end{abstract}

Advancements in rootstock breeding and selection have revolutionized the manner in which apples are grown throughout the world. In modern production systems, selection of an appropriate rootstock is as important to the viability and success of a new planting as the choice of fruiting cultivar. Rootstocks affect a number of horticultural attributes, including winter hardiness, fruit size, precocity, productivity, tree vigor, and disease resistance (Cummins and Aldwinckle, 1983; Momol et al., 1998; Westwood, 1988). Continued breeding and selection of novel rootstock cultivars promotes improved

Received for publication 6 Apr. 2007. Accepted for publication 24 June 2007.

This work was partially funded by the Apple Research and Development Program (ARDP) and Regional Research Hatch Funds through the NC140 national rootstock project.

We thank Jason Osborne for his work in the orchard performance trial and John Barnard for statistical advice.

${ }^{1}$ To whom reprint requests should be addressed; e-mail hsa1@cornell.edu or tlr1@cornell.edu
Winslow et al.], is a common bacterial disease of rosaceous plants (Vanneste and Eden-Greene, 2000). Fire blight affects multiple stages of tree development, and disease outbreaks can lead to considerable losses resulting from reduction in yield and tree replacement. Although most commonly associated with blossom or shoot infection, the rootstock phase of fire blight is prevalent in young dwarf orchards (Robinson et al., 2006). Rootstock blight occurs when bacteria, which initially enter the tree through blossom or shoot infection, travel systemically through the vascular system into the rootstock without causing visible symptoms (Momol et al., 1998). Rootstock infection may also occur to a lesser extent through wounds and infected rootstock suckers (Vanneste and Eden-Greene, 2000). The biological factors that induce disease development remain unclear; however, once bacteria enter the rootstock, no cultural control or chemical treatment can prevent disease development (Norelli et al., 2003).

High-density systems rely mainly on the rootstock 'M.9', a highly productive dwarfing rootstock, which is particularly susceptible to rootstock blight. In heavy fire blight years under natural conditions, tree losses greater than $50 \%$ are common for orchards planted on 'M.9' rootstock (Ferree et al., 2002; Norelli et al., 2003; Robinson et al., 2006). Severe tree loss can be devastating to profitability in high-density systems where initial establishment costs are substantial. New high-performance, disease-resistant rootstocks are necessary to alleviate grower reliance on 'M.9' (Marini et al., 2006b).

The Geneva ${ }^{\circledR}$ rootstock series, originating from the Geneva NY Breeding Program, a joint venture between the USDA-ARS and Cornell University, are the leading fire blightresistant rootstocks commercially available (Johnson et al., 2001; Norelli et al., 2003). Geneva $^{\circledR}$ rootstocks exhibit high cumulative yield efficiency in multiple size classes combined with enhanced disease and, in some cases insect, resistance (Autio et al., 2005a, 2005b; Cummins and Aldwinckle, 1983; Robinson et al., 2006). Norelli et al. (2003) determined 'G.16' and 'G.30' suffered 70\% less rootstock blight-related tree mortality than either 'M.26' or 'M.9' in both inoculated and naturally infected field trials.

The objective of this work was to evaluate the Geneva ${ }^{\circledR}$ rootstocks as well as several elite rootstock clones from breeding programs around the world for both horticultural performance (dwarfing and yield efficiency) and resistance to rootstock blight when grafted to three economically important scion cultivars, 'Gala', 'Honeycrisp', and 'Golden Delicious'.

\section{Materials and Methods}

In 2002, duplicate, replicated rootstock trials were planted at two locations at the New York State Agricultural Experiment Station, Geneva, NY. The two trials were separated by $1000 \mathrm{~m}$. One of the plots was 
used for evaluation of horticultural performance of rootstock clones and the other to evaluate rootstock resistance to rootstock blight. Within each plot, three subplots were planted each with a different scion cultivar ('Royal Gala', 'Golden Delicious', and 'Honeycrisp'). For each subplot, a randomized complete block experimental design was used. There were 19 rootstock clones with 'Gala', 46 with 'Golden Delicious', and 22 with 'Honeycrisp'. Rootstock clones included appropriate Malling rootstock controls and other rootstocks of interest from around the world (Table 1). With 'Gala', there were seven single tree replications of each rootstock, whereas with both 'Golden Delicious' and 'Honeycrisp', there were 10 single tree replications of each rootstock clone. 'Gala' trees were grown at Treco Nursery, Woodburn, OR, and the 'Golden Delicious' and 'Honeycrisp' trees were

Table 1. Apple rootstocks grown for 5 years with Gala, Golden Delicious, or Honeycrisp as the scion at Geneva, NY.

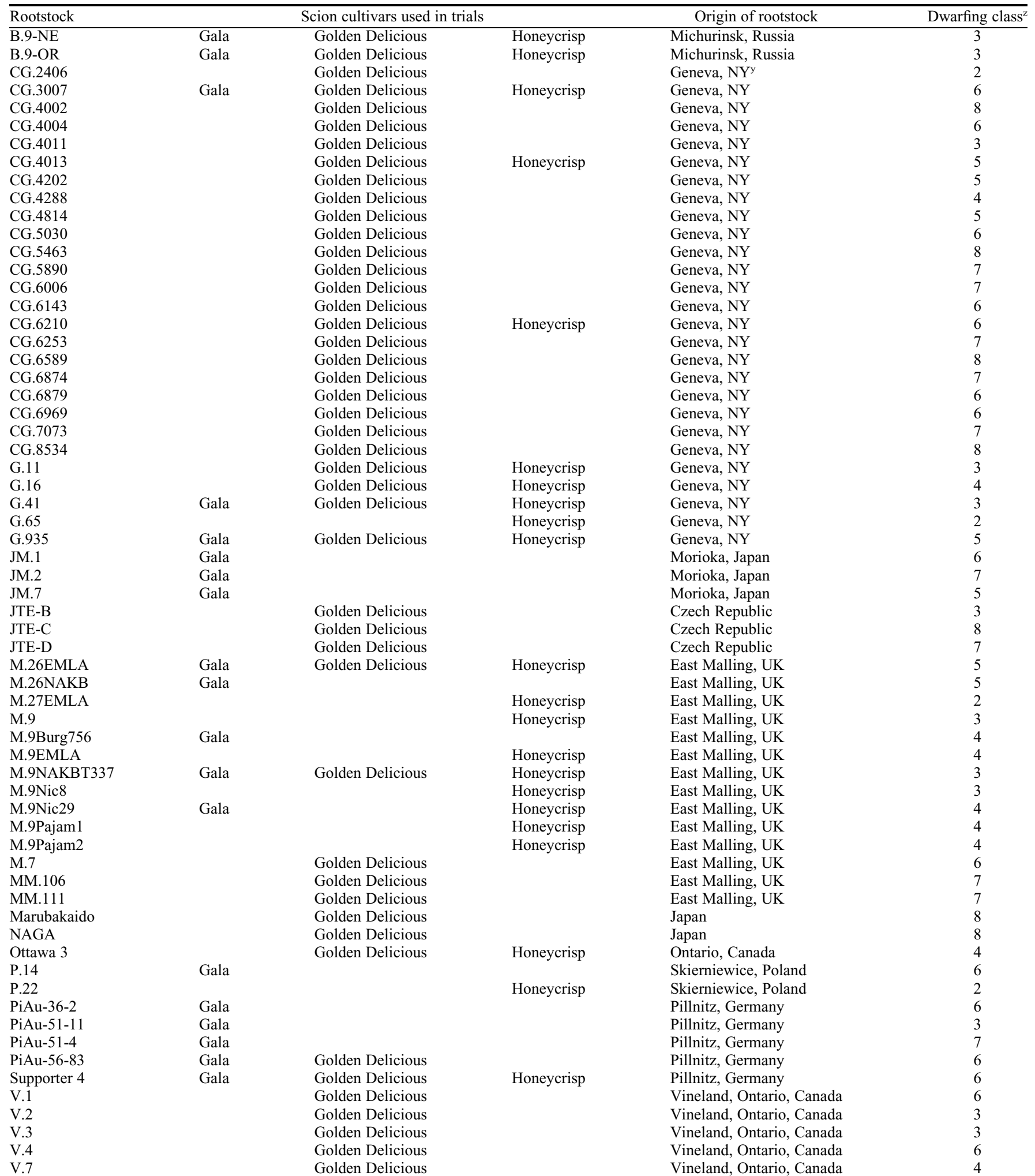

${ }^{2}$ Rootstocks dwarfing class is a range from 1 to 10 representing with $1=10$ and $10=100 \%$ the size of a tree on a full vigor seedling rootstock. Size classification according to Johnson et al. (2001).

${ }^{\mathrm{y}}$ Cornell University-USDA-ARS, New York State Agricultural Experiment Station, Geneva, NY. 
grown in a nursery at the New York State Agricultural Experiment Station, Geneva, NY.

The horticultural plot had a tree spacing of $2.5 \times 4.5 \mathrm{~m}$, whereas the fire blight plot had a spacing of $1 \times 3 \mathrm{~m}$. The two plots were planted on fine sandy loam soil with $4 \%$ organic matter. Both plots had previously been planted to apples and were fumigated with Telone C-17 (Dow AgroSciences LLC, Indianapolis, IN) $\left(375 \mathrm{~L} \cdot \mathrm{ha}^{-1}\right)$ in early Sept. 2001, the fall before planting. Trees were planted with bud union height $10 \mathrm{~cm}$ above the soil line in early May 2002 and were minimally pruned at planting. The leader was not headed but lateral branches, if present, were shortened by one-third. A support trellis was installed in mid-Summer 2002. Trees were trained to the vertical axis system (Robinson, 2003), which included leaving the leader unheaded and removing only one to two large vigorous lateral branches each year. Branches were removed at the point of origin on the trunk using an angle cut. Trees received $\mathrm{N}$ at $60 \mathrm{~kg} \cdot \mathrm{ha}^{-1}$ as ammonium nitrate each spring at budbreak and $\mathrm{K}_{2} \mathrm{O}$ at 120 $\mathrm{kg} \cdot \mathrm{ha}^{-1}$ as $\mathrm{KCl}$ each November. Trees were not irrigated. In 2002, 2003, 2004, and 2006, adequate rainfall was received each month of the growing season (greater than $75 \mathrm{~mm} /$ month). In 2005, moderate drought occurred in late June and July. Trees were defruited in the first 2 years (2002 and 2003) and then allowed to crop in 2004 to 2006. In 2004, trees were hand-thinned to a single fruit per cluster, whereas in 2005 and 2006, trees were chemically thinned by spraying them with $5 \mathrm{mg} \cdot \mathrm{ha}^{-1}$ NAA (Fruitone-N, AMVAC Chemical Corp., Los Angeles, CA) tank mixed with $600 \mathrm{mg} \cdot \mathrm{ha}^{-1}$ Carbaryl (Sevin XLR; Bayer Crop Science, Research Triangle Park, NC) using $935 \mathrm{~L} \cdot \mathrm{ha}^{-1}$ of water at $10-\mathrm{mm}$ fruit size. Chemical thinning was effective and no additional hand-thinning was necessary.

In the horticultural plot, fruit number and fruit weight were recorded per tree in 2004 to 2006. At the end of the experiment (Nov. 2006), tree survival, tree circumference, tree height, canopy width in two compass directions, and number of root suckers per tree were recorded. Canopy volume was calculated assuming a conical canopy shape. The distance below the bottom branch to the soil was not included in the volume calculation. Data were analyzed separately for each scion cultivar with replicate as a random effect and rootstock as fixed effect using SAS Proc Mixed procedure $\left(\mathrm{y}_{i j}=\mathrm{m}+\mathrm{r}_{i}+\mathrm{s}_{j}+\mathrm{e}_{i j}\right)$ (SAS Institute, Cary, NC). Means were adjusted for missing trees using the least squares means procedure. Mean separation was determined using least significant difference with a $P$ value of 0.05

In the disease resistance plot, a subset of 55 dwarf and semidwarf rootstocks was compared for their sensitivity to rootstock blight infection. In 2005, trees were inoculated at $60 \%$ bloom using a backpack sprayer containing $1 \times 10^{7}$ colony-forming units $/ \mathrm{mL}$ of E. amylovora strain E4001a (Ea266) in potassium phosphate buffer $(0.05 \mathrm{M})$. Strain E4001a was selected based on its virulence and ability to overcome certain sources of resistance (Norelli and Aldwinckle, 1986; Norelli et al., 1987). Percent infection was measured by recording the proportion of infected blossom clusters out of 50 randomly selected blossom clusters for each inoculated tree. Incidence of rootstock blight infection was based on the presence of diagnostic symptoms, primarily bacterial ooze emitted from the rootstock. Subsequent tree death or premature reddening of tree foliage confirmed frequency of rootstock blight. Trees were evaluated for rootstock blight symptoms four times during the 2005 season: 21 July, 10 Aug., 6 Oct., and 19 Oct. 2005. Data were analyzed with logistic regression to determine likelihood of developing rootstock blight using a $P$ value of 0.05 . Based on the parameters of logistic regression, rootstock clones with no observed rootstock blight were excluded from analysis and designated resistant for that particular scion rootstock combination.

\section{Results}

\section{Orchard performance}

'Gala' as the scion. 'Gala' trees with the smallest trunk cross-sectional area (TCA) were on 'B.9' sourced from The Netherlands ('B.9'-NE); 'B.9' sourced from Oregon ('B.9'-OR); and 'G.41', 'G.935', and 'M.9NAKBT337' (Table 2). There was no significant difference between trees on 'B.9'-OR or 'B.9'-NE. The vigorous clones of 'M.9', 'M.9Burg756' and 'M.9Nic29', produced trees larger than 'M.9NAKBT337' similar in size to 'M.26', but the difference after 5 years was not significant. Trees with 'M.26NAKB' were not significantly different from those with 'M.26EMLA'. Among the JM rootstocks, 'JM.7' and 'JM.1' were the most dwarfing and produced trees similar in size to the vigorous clones of 'M.9', whereas 'JM.2' produced trees significantly larger. Among the $\mathrm{PiAu}$ rootstocks, 'PiAu-51-11' was the most dwarfing and produced trees similar to 'M.9Nic29', whereas trees with other three PiAu stocks ('PiAu-51-44', 'PiAu-36-2', and 'PiAu-56-83') were significantly larger. Among the Geneva ${ }^{\circledR}$ rootstocks, 'G.41' was the most dwarfing followed by 'G.935', which produced trees similar in size to 'M.9T337'. 'CG.3007' produced trees significantly larger than other Geneva and CG rootstocks, and 'CG.3003' trees were the largest in the trial.

Tree canopy volume measurements and TCA measures were generally correlated (Fig. 1). Exceptions included trees on 'P.14' and 'M.9Burg756', which had larger canopies than predicted based on their TCA, whereas 'PiAu-51-11' and 'PiAu-51-4' produced trees with smaller canopies than predicted.

The greatest number of root suckers (four to six) was recorded with 'G.935' and 'B.9'NE (Table 2). The majority of rootstocks had few, if any, root suckers. Tree survival did not differ significantly among rootstocks, but 'G.935' had the lowest survival overall (Table 2).

The greatest cumulative yield was with 'JM.2' (46 kg) followed by 'G.935' (44 kg) and 'JM.7' (31 kg) (Table 2). The various clones of 'M.9' and many of the other rootstocks had intermediate yield, whereas the $\mathrm{PiAu}$ stocks, 'P.14', and 'M.26', had the lowest yield.

The greatest cumulative yield efficiency (yield adjusted for tree size) was with trees on 'B.9'-NE, 'G.935', 'G.41', and 'B.9'OR followed by 'JM.7', 'M.9Nic29', 'M.9NAKBT337', 'JM.1', 'JM.2', and 'M.26NAKB'. Clones of 'M.9' and 'M.26' along with 'Supporter 4' had intermediate yield efficiency, whereas the PiAu stocks and 'P.14' had the lowest yield efficiency. Yield efficiency was negatively correlated with TCA (Fig. 2). Exceptions included 'B.9'NE, 'G.935', and 'JM.2', which had higher yield efficiencies than predicted from their TCA, whereas 'PiAu-51-11' had lower yield efficiency than predicted from its TCA.

Average fruit size was largest with 'JM.1', 'M.9Burg756', and 'Supporter 4', whereas 'CG.3007', 'PiAu-56-83', 'G.935', and 'M.26EMLA' had the smallest fruit size (Table 2). The remaining rootstocks had intermediate fruit size that did not significantly differ from each other.

'Golden Delicious' as the scion. 'Golden Delicious' trees with the smallest TCA were on 'CG.2406' (Table 2). Trees, similar to 'M.9', were on 'CG.4013', 'V.2', 'V.3', 'B.9'-NE, 'G.16', 'CG.4011', 'Ottawa 3', 'B.9'-OR, 'G.11', 'G.41', 'JTE-B', and 'V.7'. There was no significant difference between trees on 'B.9'-OR and 'B.9'-NE. A third group was similar in size to 'M.26' and included 'G.935', 'Supporter 4', 'CG.4814', 'CG.4202', 'CG.6210', and 'CG.6969' with seven lesser known CG rootstocks. A fourth group, comparable in size to 'M.7' and 'MM.111' trees, included 'V.1', 'V.4', 'JTE-D', 'CG.6874', 'CG.6006', and two lesser-known CG rootstocks. The most vigorous group included 'Marubakaido', 'PiAu56-83', 'JTE-C', and four CG rootstocks.

Tree canopy volume measurements and TCA measures were generally correlated (Fig. 1). Exceptions included 'CG.6006', which had a larger canopy than predicted from its TCA, whereas 'JTE-B' had a smaller canopy than predicted from its TCA.

The greatest number of root suckers (nine to 10) was recorded with 'CG.5030', 'M.7', and 'B.9'-NE (Table 2). 'CG.4288', 'CG.4011', 'CG.6879', and 'CG.6143' had four to six root suckers, whereas the remaining rootstocks had fewer than three. Tree survival was significantly lower than $100 \%$ with 'V.3' and 'V.4'. Tree survival for the remaining rootstocks did not differ significantly from $100 \%$ (Table 2 ).

The greatest cumulative yield (19 to $23 \mathrm{~kg} / \mathrm{tree})$ was with trees on 'CG.6006' followed by 'CG.4011', 'B.9'-NE, and 'CG.6969' (Table 2). An intermediate yielding group included 'CG.6874', 'CG.4288', 


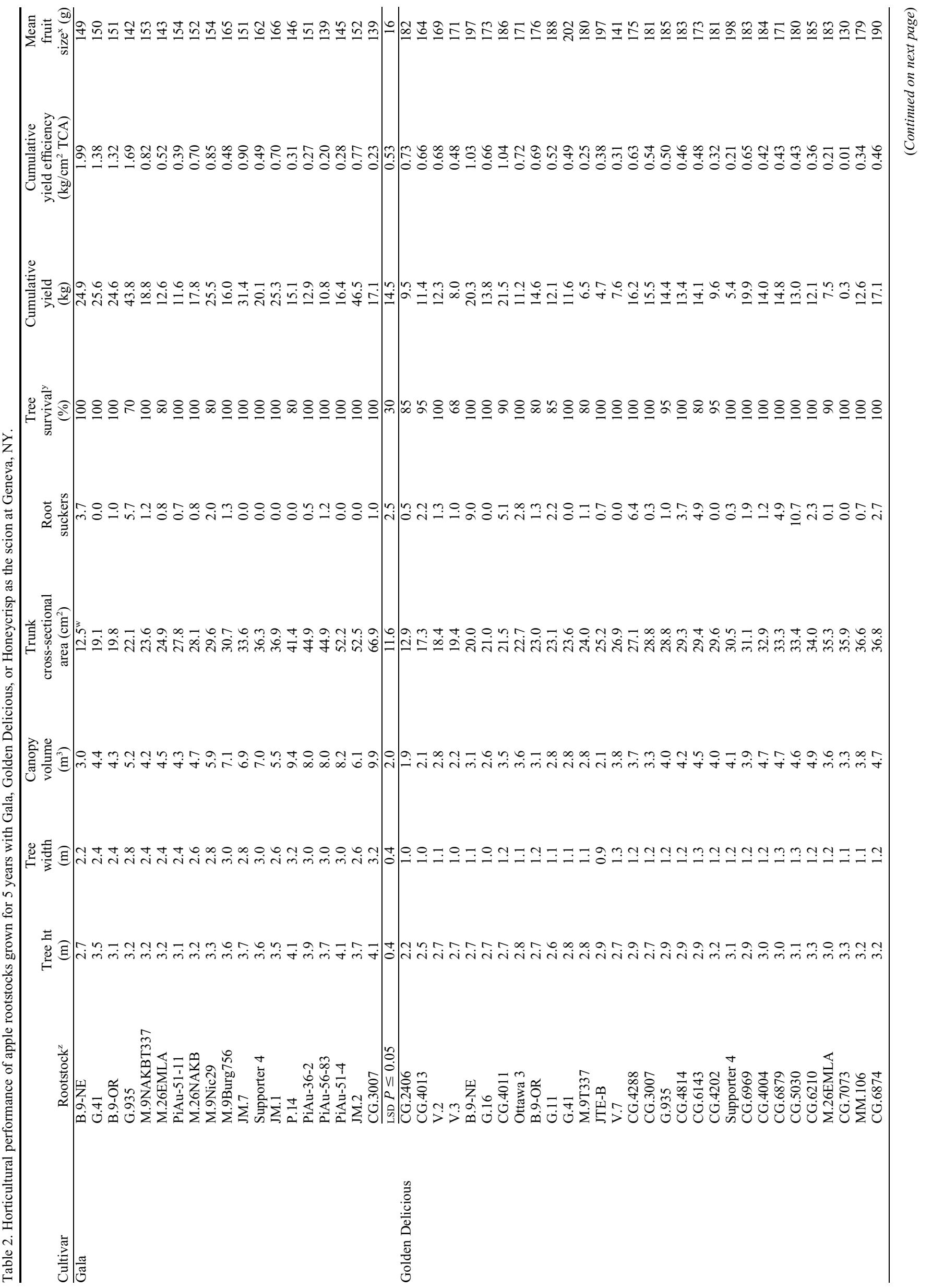




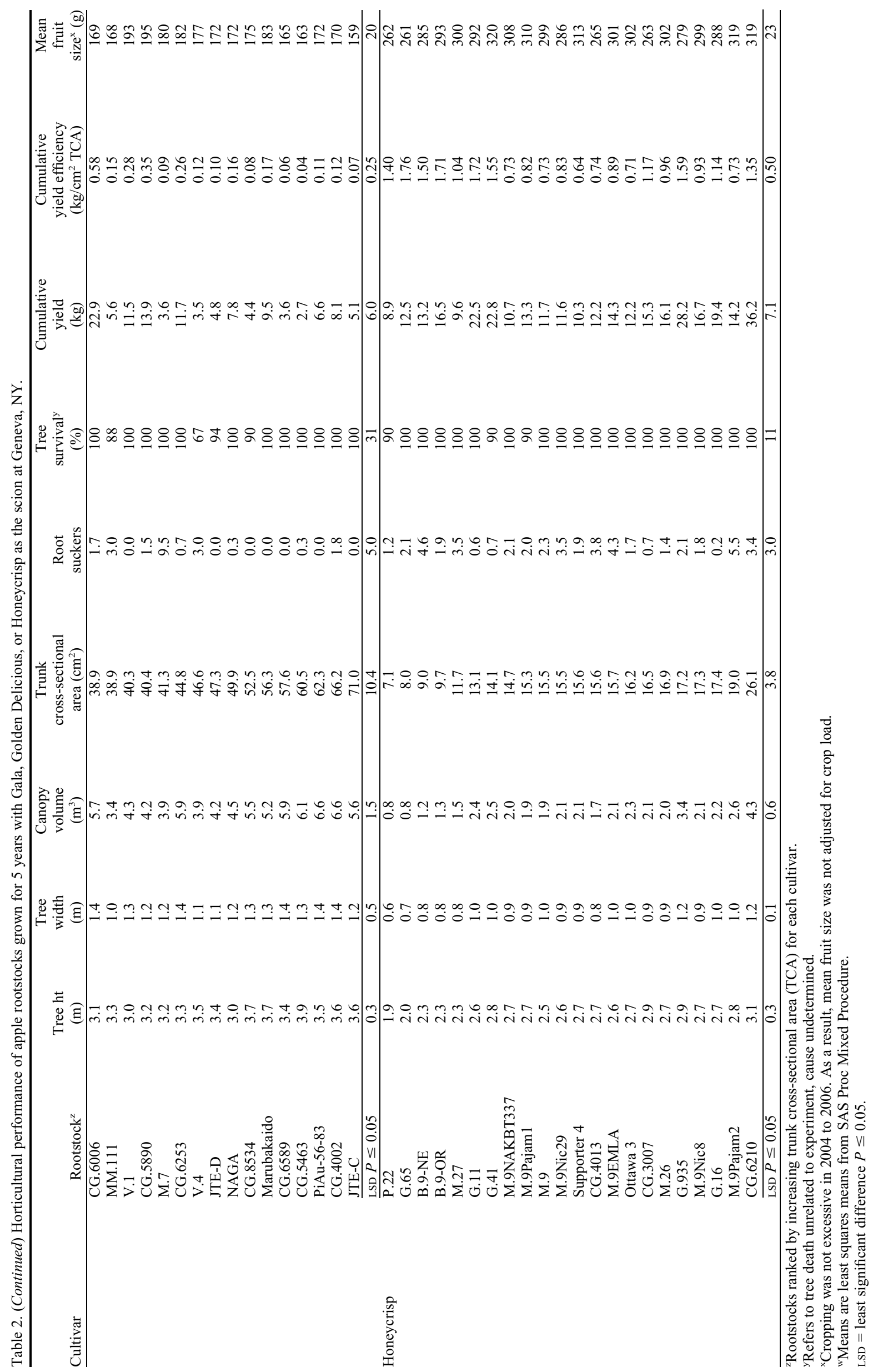

HortScience Vol. 42(7) December 2007 


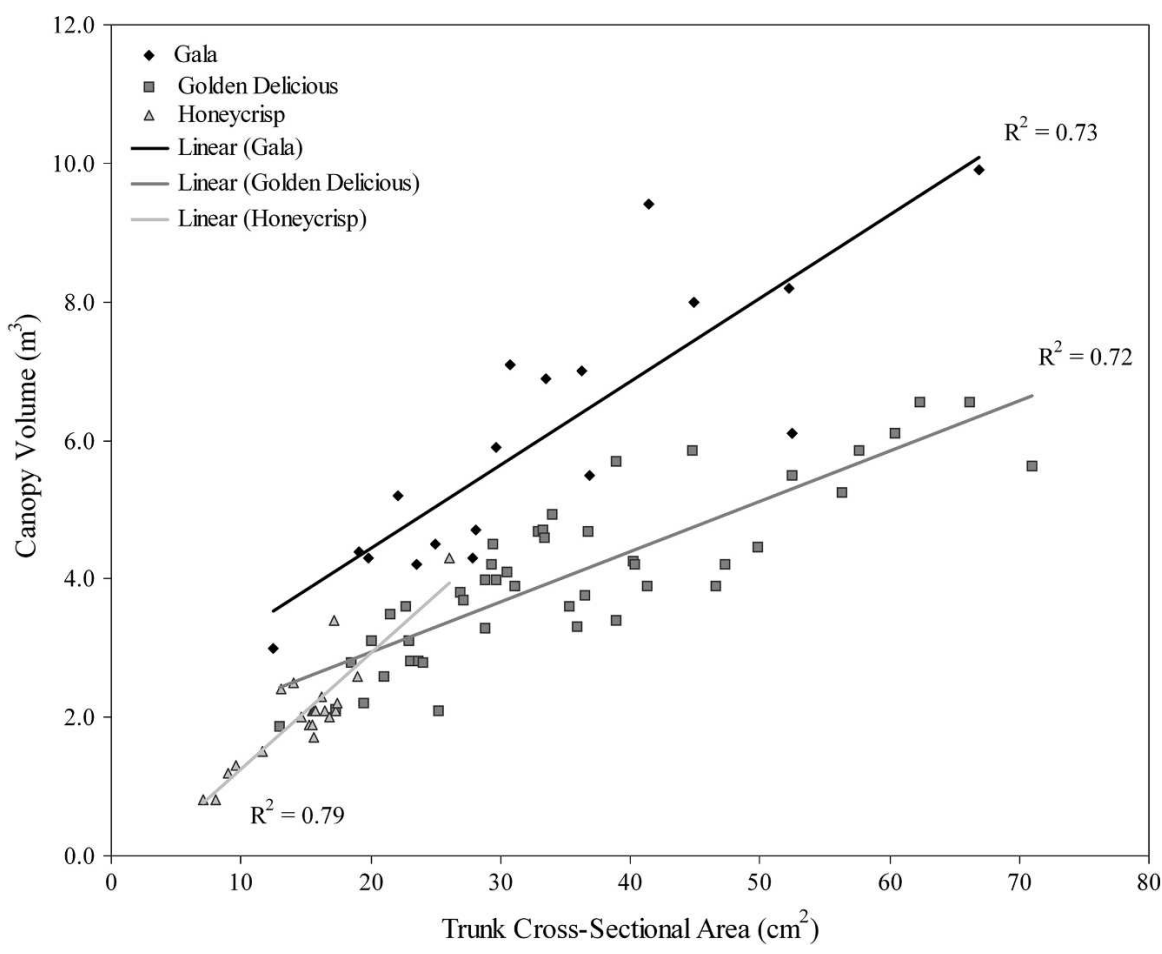

Fig. 1. Relationship of trunk cross-sectional area and canopy volume of 64 apple rootstocks with three scion cultivars after 5 years.

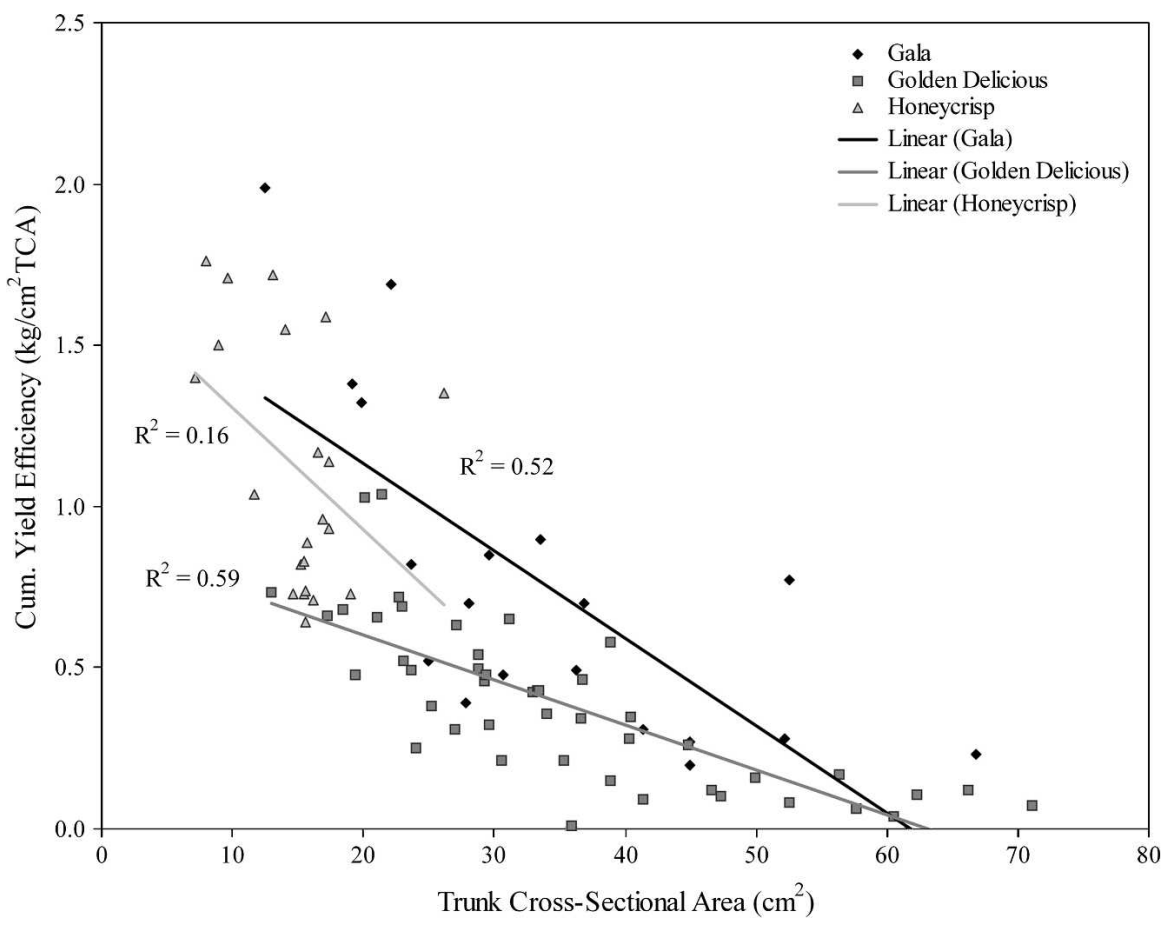

Fig. 2. Relationship of trunk cross-sectional area and cumulative yield efficiency of 64 apple rootstocks with three scion cultivars after 5 years.

'CG.3007', 'CG.6874', 'B.9'-OR, 'G.935', 'CG.5890', 'G.16', 'CG.4814', 'CG.5030', 'MM.106', 'V.2', 'G.11', 'CG.6210', 'CG.4013', 'CG.6253', 'G.41', 'V.1', and 'Ottawa 3'. The lowest yielding group included 'M.9', 'M.26', 'V.3', 'V.7', 'Supporter 4', 'MM.111', 'M.7', 'V.4', and many others. Many of the trees planted with vigorous rootstocks had low yield. porter 4' had intermediate to low yield efficiency, whereas the PiAu stocks and 'P.14' had the lowest yield efficiency. Yield efficiency was negatively correlated with TCA (Fig. 2). Exceptions included 'B.9'NE, 'CG.4011', and 'CG.6006', which had higher yield efficiencies than predicted from their TCA, whereas 'M.9T337', 'Supporter 4', 'CG.7073', and 'M.7' had lower yield efficiency than predicted from their TCA.

Average fruit size was largest with 'JM.1', 'M.9Burg756', and 'Supporter 4', whereas 'CG.3007', 'PiAu-56-83', 'G.935', and 'M.26EMLA' had the smallest fruit size (Table 2). The remaining rootstocks had intermediate fruit size and did not differ significantly from each other.

'Honeycrisp' as the scion. 'Honeycrisp' trees with the smallest TCA were on 'P.22', 'G.65', 'B.9'-NE, 'B.9'-OR, and 'M.27'. A slightly larger group, similar in size to 'M.9', included 'G.11', 'G.41', 'Supporter 4', 'CG.4013', and three clones of 'M.9' (T337, Pajam1, and Nic29). A third group, which was similar in size to 'M.26', included 'Ottawa 3', 'CG.3007', 'G.935', 'G.16', and the vigorous 'M.9' clones (Nic8 and Pajam2) (Table 2). 'CG.6210' was significantly larger than other CG rootstocks and was the largest rootstock in the trial.

Tree canopy volume measurements and TCA measures were generally correlated (Fig. 1). Exceptions included 'G.935', which had a larger canopy volume than predicted from its TCA.

The greatest number of root suckers (three to six) was recorded with 'M.9Pajam2', 'B.9Europe', 'M.9EMLA', 'CG.4013', 'M.27', 'M.9Nic29', and 'CG.6210'. The remaining rootstocks had fewer than three root suckers. Tree survival did not differ significantly among rootstocks (Table 2).

The greatest cumulative yield $(36.2 \mathrm{~kg})$ was with 'CG.6210' followed by 'G.935', 'G.41', 'G.11', and 'G.16'. 'P.22' and 'M.27' had the lowest yield. The remaining rootstocks had intermediate yield.

The rootstocks with the highest yield efficiency were 'G.65', 'G.11', 'B.9'-OR, 'G.935', 'G.41', 'B.9'-NE, 'P.22', and 'CG.6210'. The remaining rootstocks did not differ in cumulative yield efficiency, but 'Supporter 4', 'M.9', and 'M.9NAKBT337' had the lowest overall yield efficiency. Yield efficiency was negatively correlated with TCA (Fig. 2). Exceptions included 'CG.6210', 'G.935', 'G.11', 'G.41', 'B.9'$\mathrm{OR}$, and ' $\mathrm{G} .65$ ', which had higher yield efficiencies than predicted from their TCA, whereas 'M.9', 'Supporter 4', 'CG.4013', and 'Ottawa 3' had lower yield efficiency than predicted from their TCA.

Average fruit size was largest with 'G.41', 'CG.6210', 'M.9Pajam2', 'Supporter 4', 'M.9Pajam1', 'M.9T337', 'Ottawa 3', 'M.26', and 'M.27', whereas 'G.65', 'P.22', 'CG.3007', and 'CG.4013' had the smallest fruit size (Table 2). All 'M.9' rootstocks had large fruit size except for 'M.9Nic29'. The two clones of 'B.9' had smaller fruit size than 'G.41' or 'CG.6210'. The remaining 
rootstocks had intermediate fruit size and did not differ significantly from each other.

\section{Rootstock blight experiment}

In 2004, a natural epidemic of fire blight developed in the test orchard, and several 'Gala' and 'Honeycrisp' trees developed rootstock blight as a result. Trees with rootstock infections were recorded and removed before the 2005 season. Shoot blight was pruned out of the orchard at the end of 2004 and did not affect the 2005 inoculation trial. Incidence of blossom infection in 2005 was uniform across all three cultivars. Symptoms were first observed on 21 July 2005 and new infections continued to develop through Oct. 2005. 'Gala' and 'Honeycrisp' suffered severe shoot blight as a result of the blossom inoculation. The canopies of these two cultivars were largely destroyed by fire blight such that during the Winter 2006 pruning, $94 \%$ of 'Gala' and $60 \%$ of 'Honeycrisp' trees had most of the canopy removed regardless of rootstock infection. The cultivar 'Golden Delicious' had noticeably less shoot blight and no trees were removed in 2006. The degree of rootstock mortality was likewise elevated in cultivars 'Gala' and 'Honeycrisp' compared with 'Golden Delicious'. Based on these observations and the low number of rootstocks shared between cultivars, data from 'Gala' and 'Honeycrisp' trees were combined and analyzed separately from 'Golden Delicious'. Logistic regressions indicated the probability of developing rootstock blight was significantly affected by rootstock for both 'Gala/Honeycrisp' and 'Golden Delicious' cultivars at $P=0.05$ (Table 3). The effect of scion and the interaction of scion and rootstock on rootstock blight were not significant for the 'Gala/ Honeycrisp' analysis.

'Gala' and 'Honeycrisp' as the scion. Twelve rootstock cultivars were found to have elevated probability of developing rootstock blight with 'Gala' or 'Honeycrisp' as the scion (Table 4). Susceptible rootstocks included all four 'M.9' clones (Burg756, EMLA, NAKBT337, and Nic29), the three 'M.26' clones (M.26, EMLA, NAKB) as well as 'Ottawa 3', 'P.22', 'JM.2', 'Supporter 4', and 'M.27'. Eight rootstocks had a significantly lower probability of developing rootstock blight, and two rootstocks were designated resistant because they had no rootstock infection. Among these, 'PiAu51-4' and 'P.14' were slightly more resistant to rootstock blight than 'PiAu-56-83'. There was no significant difference between 'B.9'OR and 'B.9'-NE. All of the Geneva rootstocks evaluated had high levels of resistance to rootstock blight.

'Golden Delicious' as the scion. There was a marked reduction in rootstock blight with 'Golden Delicious' as the scion compared with either 'Gala' or 'Honeycrisp'. Only three rootstocks had elevated probability of developing rootstock blight, 'M.26', 'Ottawa 3', and 'M.9EMLA', reflecting the results for 'Gala' and 'Honeycrisp'. Of the 42 rootstocks tested, 35 failed to develop any

Table 3. Effect of rootstock on the probability of developing rootstock blight.

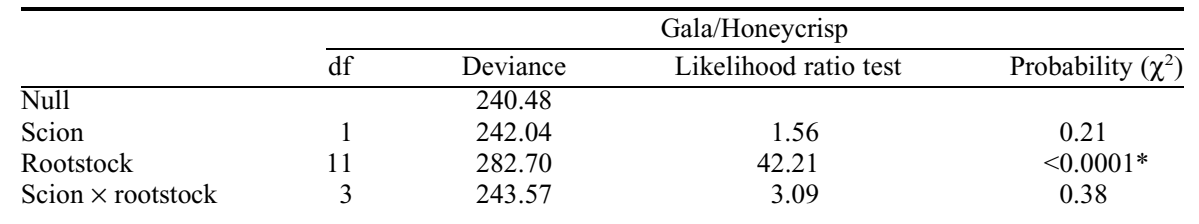

Golden Delicious

\begin{tabular}{lcccc} 
Null & \multicolumn{3}{c}{ Golden Delicious } \\
Rootstock & 6 & 67.90 & 16.91 & $0.01 *$ \\
\hline *Significant at $P \leq 0.05$ & & &
\end{tabular}

df $=$ degrees of $f$ reed

Table 4. Effect of rootstock on probability of developing rootstock blight with either Gala or Honeycrisp as the scion.

\begin{tabular}{|c|c|c|c|c|c|c|}
\hline Rootstock & $\begin{array}{c}\text { Mean } \\
\text { blossom } \\
\text { infection } \\
2005(\%)\end{array}$ & $\begin{array}{c}\text { Rootstock } \\
\text { blight } \\
\text { (2004) }\end{array}$ & $\begin{array}{c}\text { Rootstock } \\
\text { blight } \\
(2005)\end{array}$ & $\begin{array}{l}\text { Tree } \\
\text { total }\end{array}$ & $\begin{array}{l}\text { Proportion } \\
\text { infected }\end{array}$ & $\mathrm{SE}$ \\
\hline M.26 & 60 & 1 & 13 & 15 & 0.93 & $0.06^{*}$ \\
\hline M.9NAKBT337 & 89 & 1 & 5 & 7 & 0.86 & $0.13 *$ \\
\hline Ottawa 3 & 70 & 1 & 15 & 19 & 0.84 & $0.08 *$ \\
\hline M.9EMLA & 76 & & 15 & 19 & 0.79 & 0.09 \\
\hline M.26EMLA & 85 & 1 & 5 & 8 & 0.75 & $0.15^{*}$ \\
\hline M.26NAKB & 88 & & 6 & 9 & 0.67 & $0.16^{*}$ \\
\hline P.22 & 80 & 2 & 10 & 16 & 0.75 & $0.11 *$ \\
\hline JM.2 & 95 & 1 & 2 & 5 & 0.60 & $0.22 *$ \\
\hline M.9Nic29 & 85 & & 4 & 7 & 0.57 & $0.19 *$ \\
\hline M.9Burg756 & 87 & 1 & 4 & 9 & 0.56 & $0.17 *$ \\
\hline Supporter 4 & 81 & & 12 & 25 & 0.48 & $0.10^{*}$ \\
\hline M.27 & 86 & & 5 & 20 & 0.40 & $0.11 *$ \\
\hline PiAu-56-83 & 79 & & 2 & 9 & 0.22 & 0.14 \\
\hline G.935 & 71 & & 1 & 8 & 0.13 & 0.12 \\
\hline G.11 & 81 & & 2 & 17 & 0.12 & 0.08 \\
\hline G.65 & 83 & 1 & 0 & 10 & 0.10 & 0.09 \\
\hline G.41 & 84 & & 1 & 26 & 0.04 & 0.04 \\
\hline P.14 & 90 & & 1 & 10 & 0.10 & 0.09 \\
\hline B.9-NE & 70 & 1 & 0 & 19 & 0.05 & 0.05 \\
\hline B.9-OR & 73 & & 1 & 29 & 0.03 & 0.03 \\
\hline $\mathrm{PiAu}-51-4$ & 82 & & 0 & 9 & $\mathrm{NA}^{\mathrm{z}}$ & \\
\hline G.16 & 72 & & 0 & 18 & NA & \\
\hline
\end{tabular}

${ }^{\mathrm{z}} \mathrm{NA}=$ not analyzed. No rootstock blight recorded during 2004 to 2005 seasons.

*Significant probability of developing rootstock blight.

observed rootstock blight symptoms despite high percentages of flower infection (Table 5). As a group, the Geneva rootstocks as well as the Vineland and JTE series demonstrated high levels of resistance to rootstock blight. Like with 'Gala' and 'Honeycrisp', there was no significant difference between 'B.9'-OR and 'B.9'-NE with regard to disease resistance. Development of rootstock blight was not significantly affected by scion cultivar in nine of the 10 rootstocks that were evaluated in both cultivar groups. 'M.26', 'M.9EMLA', and 'Ottawa 3', had less overall rootstock blight with 'Golden Delicious' as the scion. Conversely, 'Supporter 4' was found to be highly susceptible with 'Gala' and 'Honeycrisp' as the scion but had no observed rootstock blight with 'Golden Delicious' as the scion.

\section{Discussion}

Results from the three cultivars tested varied slightly, but overall rootstock responses with regard to size control and yield efficiency were consistent across culti- vars (Autio et al., 2005a, 2005b). Cumulative yield efficiency provided a uniform method for comparing rootstock productivity. The close correlation between canopy volume and TCA (Fig. 1), with few exceptions, supported the use of TCA as a comprehensive measure of tree size for trees that had not been containment-pruned. Based on the relationship between canopy size and production potential, it was not unexpected that the most dwarfing rootstocks had the highest yield efficiency. These results support previous research in which smaller canopy volume coupled with higher tree density increased cumulative yield potential of an orchard site (Hampson et al., 2002, 2004a, 2004b; Robinson and Lakso, 1991). However, there were notable exceptions to the rule that dwarfing rootstocks are the most yield-efficient. 'CG.6006' with 'Golden Delicious' and 'CG.6210', and 'G.935' with 'Honeycrisp', all semidwarfing rootstocks, had higher yield efficiency than expected for their tree size. Similarly, several dwarfing rootstocks showed lower than expected yield efficiency with 'Honeycrisp'. 'Honeycrisp', 
Table 5. Effect of rootstock on probability of developing rootstock blight with Golden Delicious as the scion.

\begin{tabular}{|c|c|c|c|c|c|}
\hline Rootstock & $\begin{array}{c}\text { Mean blossom } \\
\text { infection } 2005(\%)\end{array}$ & $\begin{array}{c}\text { Rootstock } \\
\text { blight }(2005)^{\mathrm{z}}\end{array}$ & Tree total & $\begin{array}{l}\text { Proportion } \\
\text { infected }\end{array}$ & $\mathrm{SE}$ \\
\hline M.26 & 74 & 6 & 9 & 0.67 & $0.16^{*}$ \\
\hline Ottawa 3 & 70 & 6 & 10 & 0.60 & $0.15 *$ \\
\hline M.9EMLA & 84 & 4 & 10 & 0.40 & $0.15 *$ \\
\hline G.11 & 79 & 2 & 10 & 0.20 & 0.13 \\
\hline CG.4288 & 78 & 1 & 10 & 0.10 & 0.09 \\
\hline CG.6210 & 76 & 1 & 10 & 0.10 & 0.09 \\
\hline B.9-NE & 68 & 1 & 10 & 0.10 & 0.09 \\
\hline B.9-OR & 68 & 0 & 10 & $\mathrm{NA}^{\mathrm{y}}$ & \\
\hline G.41 & 77 & 0 & 7 & NA & \\
\hline G.16 & 65 & 0 & 10 & NA & \\
\hline G.935 & 77 & 0 & 10 & NA & \\
\hline CG.2406 & 73 & 0 & 10 & NA & \\
\hline CG.3007 & 78 & 0 & 10 & NA & \\
\hline CG.4002 & 77 & 0 & 10 & NA & \\
\hline CG.4004 & 72 & 0 & 10 & NA & \\
\hline CG.4013 & 70 & 0 & 10 & NA & \\
\hline CG.4202 & 79 & 0 & 9 & NA & \\
\hline CG.4814 & 71 & 0 & 9 & NA & \\
\hline CG.5030 & 74 & 0 & 10 & NA & \\
\hline CG.5463 & 80 & 0 & 10 & NA & \\
\hline CG.5890 & 75 & 0 & 10 & NA & \\
\hline CG.6006 & 81 & 0 & 10 & NA & \\
\hline CG.6143 & 79 & 0 & 10 & NA & \\
\hline CG.6253 & 73 & 0 & 10 & NA & \\
\hline CG.6589 & 86 & 0 & 7 & NA & \\
\hline CG.6874 & 75 & 0 & 10 & NA & \\
\hline CG.6969 & 78 & 0 & 10 & NA & \\
\hline CG.8534 & 79 & 0 & 10 & NA & \\
\hline JTE-B & 80 & 0 & 9 & NA & \\
\hline JTE-C & 82 & 0 & 10 & NA & \\
\hline JTE-D & 80 & 0 & 8 & NA & \\
\hline M.7 & 66 & 0 & 10 & NA & \\
\hline Marubakaido & 81 & 0 & 10 & NA & \\
\hline MM.106 & 68 & 0 & 10 & NA & \\
\hline NAGA & 85 & 0 & 6 & NA & \\
\hline PiAu-56-83 & 83 & 0 & 9 & NA & \\
\hline Supporter 4 & 77 & 0 & 9 & NA & \\
\hline V.1 & 70 & 0 & 10 & NA & \\
\hline V.2 & 78 & 0 & 10 & NA & \\
\hline V.3 & 79 & 0 & 10 & NA & \\
\hline V.4 & 86 & 0 & 10 & NA & \\
\hline V.7 & 80 & 0 & 10 & NA & \\
\hline
\end{tabular}

${ }^{\mathrm{z}}$ No tree death recorded in 2004 from rootstock blight.

${ }^{\mathrm{y}} \mathrm{NA}=$ not analyzed. No rootstock blight recorded during 2005 season.

*Significant probability of developing rootstock blight.

as expected, was biennially bearing during the course of the experiment and therefore requires further testing to validate the effect of rootstock on yield efficiency. It should be noted that high yield efficiency, although important, must not be achieved at the expense of fruit size, which significantly affects crop value. During the course of this trial, however, crop load was not excessive and there was no significant relationship between yield efficiency and fruit size.

Our results indicate that several new dwarfing rootstocks exceed the productivity of 'M.9', which has been the world standard. High-density orchards with these rootstocks should produce greater yields, thus reducing costs per kg of fruit (Hampson et al., 2002; Robinson and Lakso, 1991). The few semidwarfing rootstocks that had higher than expected yield efficiency would allow higher yielding moderate-density orchards than previously possible.

Some of the fire blight-resistant rootstocks evaluated demonstrated considerable tolerance to rootstock blight during the 2004 and 2005 field seasons. Rootstock was the main factor influencing the development of rootstock blight, but a greater level of rootstock blight was observed with 'Gala/Honeycrisp' trees than with 'Golden Delicious'. 'Gala' and 'Honeycrisp' are both highly susceptible cultivars, which suffered severe shoot infection as a result of the 2005 inoculation. 'Golden Delicious' in comparison, previously described as intermediately susceptible to fire blight (Gardner et al., 1980), had less severe scion infection and lower incidence of rootstock blight. Rootstocks 'M.9' and 'M.26' each experienced a $30 \%$ reduction in disease incidence when planted with 'Golden Delicious' compared with 'Gala' or 'Honeycrisp'. Based on these observations, rootstocks evaluated only using 'Golden Delicious' as the scion require additional examination before an accurate assessment of rootstock blight sensitivity can be made. The effect of scion cultivar on rootstock blight development clearly demonstrates the need for fire blight-resistant rootstocks when planting susceptible culti- vars. Conversely, fire blight-"tolerant" rootstocks may provide a measure of protection against rootstock blight when moderately susceptible scion cultivars are being considered.

The Malling rootstocks have persisted as the standard dwarfing rootstocks for over 50 years. 'M.9' clones performed well in orchard trials, but slight variation was observed with regard to tree size and cumulative yield efficiency. The more vigorous 'M.9' clones, including 'M.9Burg756', 'M.9Nic29', and 'M.9Pajam2', produced larger than expected trees with reduced yield efficiency. Marini et al. (2006a) reported slight variation in tree size and yield among 'M.9' clones, but discrepancies were largely insignificant and varied by location. 'M.9' clones had satisfactory yield efficiency but were often inferior to more advanced rootstock selections (Table 2) as well as far more susceptible to fire blight (Tables 4 and 5). As a group, the Malling rootstocks were highly susceptible to rootstock blight with 'M.26' and 'M.9' suffering tree loss between 56 and $93 \%$ when grafted to a highly susceptible scion cultivar.

All of the Geneva rootstocks evaluated had significantly lower probability of developing rootstock blight than the standard Malling rootstocks. Even 'G.11', previously described as fire blight-tolerant (Norelli et al., 2003), had significantly less overall rootstock blight, even with the highly susceptible cultivars 'Gala' and 'Honeycrisp'. 'G.41' and 'G.935' performed exceedingly well with all cultivars, producing trees comparable in size to less vigorous 'M.9' clones with greater cumulative yield efficiency. 'G.41' and 'G.935' also maintained good fruit size, although 'Gala' fruit size was reduced with 'G.935'. 'G.16', with tree size comparable to more vigorous 'M.9' clones, had moderate yield efficiency. The main concern with 'G.16' remains its sensitivity to latent viruses, which necessitates the use of virusfree scion wood at budding (Johnson et al., 2001). Several unreleased CG rootstocks, particularly 'CG.4011' and 'CG.4013', showed considerable promise for future release, although further evaluation is necessary to verify orchard performance and disease resistance.

'B.9' rootstock from nurseries in both Oregon and The Netherlands produced trees comparable in size to the less vigorous 'M.9' clones. Although average fruit size was comparable to 'M.9', cumulative yield efficiency exceeded 'M.9' clones for all three cultivars. 'B.9' also demonstrated high levels of resistance to rootstock blight development, demonstrating its potential for sites with a history of fire blight infection. This is in contrast to initial reports that indicated 'B.9' was highly susceptible to fire blight. Those evaluations were done by inoculating 'B.9' plants directly rather than by inoculating a scion cultivar grafted on 'B.9' (Cummins and Aldwinckle, 1983; Norelli et al., 2003; Travis et al., 1999). Our data support the findings of Norelli et al. (2003) 
that showed significant resistance of 'B.9' to rootstock blight in field plantings. Anecdotal evidence from commercial orchards supports the resistance of 'B.9' to rootstock blight when tested as a grafted tree. This anomaly of susceptibility as an ungrafted plant but resistance as a rootstock is the subject of ongoing research.

Plant material of 'B.9' from The Netherlands and U.S. nursery suppliers was virtually identical in tree size, yield, fruit size, and disease resistance, but 'B.9'-NE produced significantly more rootstock suckers than 'B.9'-OR with all cultivars. Slight variation may exist in the 'B.9' population accounting for this discrepancy and other unexplained differences in nursery stock (Norelli et al., 2003). These data support anecdotal reports from nursery growers that 'B.9' is not completely genetically uniform.

Several of the Japanese JM rootstocks had promising results. All three JM rootstocks, 'JM.1', 'JM.2', and 'JM.7', had high cumulative yield efficiency and good fruit size. Unfortunately, only 'JM.2' was included in the disease resistance trial, where it proved susceptible to rootstock blight.

The PiAu rootstocks, which originated from the Dresden Pillnitz breeding program in Germany, including 'Supporter 4', produced trees larger than expected. Of the four rootstocks tested, only 'PiAu-51-11' produced a tree comparable to 'M.9' in size. As a group, the PiAu rootstocks were moderately resistant to rootstock blight, but their low yield efficiency negates the usefulness of these rootstocks in dwarf production systems.

The Vineland rootstocks, from Ontario, Canada, produced a wide range of tree sizes with varying levels of productivity. Three rootstocks 'V.2', 'V.3', and 'V.7', produced trees similar in size to 'M.9', whereas 'V.1' and 'V.4' were sized closer to 'M.26'. One major disadvantage of the Vineland series was lower than expected yields. One rootstock, 'V.2', demonstrated significant promise producing a tree equivalent in size to 'M.9' with high cumulative yield efficiency. Consistent with other Vineland rootstocks, 'V.2' was highly resistant to rootstock blight, but resistance evaluation was only done with the cultivar 'Golden Delicious'. These results support work by Cline et al. (2001) and Ferree et al. (2002) in which the Vineland series maintained a significant level of resistance to fire blight in inoculated and naturally infected field trials.

In these studies, tree loss resulting from rootstock blight was considerable. High losses using conventional rootstocks emphasize the need for novel rootstock selections that promote good orchard performance coupled with functional disease resistance. Diseaseresistant rootstocks are a reliable and costeffective method to enhance the survival of young trees during initial years of orchard establishment (Cline et al., 2001; Schupp et al., 2002). Several rootstock selections evaluated during the course of this study show considerable promise as alternatives to 'M.9' in future plantings.
These results represent the combined orchard performance and rootstock blight resistance data of 64 apple rootstocks after 5 years of orchard evaluation. Five years is often too short a time to critically evaluate rootstock performance. A complete summary after 10 years should provide more conclusive information regarding the influence of rootstock on orchard performance.

\section{Literature Cited}

Autio, W.R., T.L. Robinson, B.H. Barritt, J.A Cline, R.M. Crassweller, C.G. Embree, M.E. Garcia, G.M. Greene, E.E. Hoover, R.S. Johnson, K. Kosola, J. Masabni, M.L. Parker, R.L. Perry, G.L. Reigard, S.D. Seely, and M. Warmund. 2005a. Performance of 'Fuji' and 'McIntosh' apple trees after 5 years as affected by several dwarf rootstocks in the $1999 \mathrm{NC}$ 140 Apple Rootstock Trial. J. Amer. Pomol. Soc. 59:202-214.

Autio, W.R., T.L. Robinson, B.H. Barritt, J.A. Cline, R.M. Crassweller, C.G. Embree, M.E. Garcia, G.M. Greene, E.E. Hoover, R.S. Johnson, K. Kosola, J. Masabni, M.L. Parker, R.L. Perry, G.L. Reigard, S.D. Seely, and M. Warmund. 2005b. Performance of 'Fuji' and 'McIntosh' apple trees after 5 years as affected by several semidwarf rootstocks in the 1999 NC-140 Apple Rootstock Trial. J. Amer. Pomol. Soc. 59:192-201.

Cline, J.A., D.M. Hunter, W.G. Bonn, and M. Bijl. 2001. Resistance of the Vineland series of apple rootstocks to fire blight caused by Erwinia amylovora. J. Amer. Pomol. Soc. 55:218-221.

Cummins, J.N. and H.S. Aldwinckle. 1983. Breeding apple rootstocks. Plant Breed. Rev. 1:294-394.

Ferree, D.C., K.A. Clayton-Greene, and B. Bishop. 1993. Influence of orchard management-system on canopy composition, light-distribution, net photosynthesis and transpiration of appletrees. J. Hort. Sci. 68:377-392.

Ferree, D.C., J.C. Schmid, and B.L. Bishop. 2002. Survival of apple rootstocks to natural infections of fire blight. HortTechnology 12:239-241.

Gardner, R.G., J.N. Cummins, and H.S. Aldwinckle. 1980. Fire blight resistance in the Geneva apple rootstock breeding program. J. Amer. Soc. Hort. Sci. 105:907-912.

Hampson, C.R., H.A. Quamme, and R.T. Brownlee. 2002. Canopy growth, yield, and fruit quality of 'Royal Gala' apple trees grown for eight years in five tree training systems. HortScience 37:627-631.

Hampson, C.R., H.A. Quamme, F. Kappel, and R.T. Brownlee. 2004a. Varying density with constant rectangularity: I. Effects on apple tree growth and light interception in three training systems over ten years. HortScience 39:501-506.

Hampson, C.R., H.A. Quamme, F. Kappel, and R.T. Brownlee. 2004b. Varying density with constant rectangularity: II. Effects, on apple tree yield, fruit size, and fruit color development in three training systems over ten years. HortScience 39:507-511.

Johnson, W.C., H.S. Aldwinckle, J.N. Cummins, P.L. Forsline, H.T. Holleran, J.L. Norelli, and T.L. Robinson. 2001. The USDA-ARS/Cornell University apple rootstock breeding and evaluation program. Acta Hort. 557:35-40.

Marini, R.P., J.L. Anderson, J.A. Barden, B.H. Barritt, G.R. Brown, J. Cline, W.P. Cowgill, Jr., P.A. Domoto, D.C. Ferree, R.M. Garner, G.M. Greene, C. Hampson, P. Hirst, M.M. Kushad, J. Masabni, E. Mielke, R. Moran, C.A. Mullins, M. Parker, R.L. Perry, J.P. Privé, G.L. Reighart, T. Robinson, C.R. Rom, T. Roper, J.R.
Schupp, E. Stover, and R. Unrath. 2006a. Performance of 'Gala' on four semi-dwarf rootstocks: A ten-year summary of the 1994 NC-140 semi-dwarf rootstock trial. J. Amer. Pomol. Soc. 60:58-68.

Marini, R.P., J.L. Anderson, W.R. Autio, B.H. Barritt, J. Cline, W.P. Cowgill, Jr., R.M. Garner, A. Gauss, R. Godin, G.M. Greene, C. Hampson, P. Hirst, M.M. Kushad, E. Mielke, R. Moran, C.A. Mullins, M. Parker, R.L. Perry, J.P. Privé, G.L. Reighard, T. Robinson, C.R. Rom, T. Roper, J.R. Schupp, E. Stover, and R. Unrath. 2006b. Performance of 'Gala' on 18 dwarfing rootstocks: Ten-year summary of the 1994 NC-140 rootstock trial. J. Amer. Pomol. Soc. 60:69-83.

Momol, M.T., J.L. Norelli, D.E. Piccioni, E.A. Momol, H.L. Gustafson, J.N. Cummins, and H.S. Aldwinckle. 1998. Internal movement of Erwinia amylovora through symptomless apple scion tissues into the rootstock. Plant Dis. 82:646-650.

Norelli, J.L. and H.S. Aldwinckle. 1986. Differential susceptibility of Malus spp. cultivars Robusta-5, Novole, and Ottawa-523 to Erwinia amylovora. Plant Dis. 70:1017-1019.

Norelli, J.L., H.S. Aldwinckle, S.V. Beer, and R.C. Lamb. 1987. The effects of virulence of Erwinia amylovora on the evaluation of fire blight resistance in Malus. Phytopathology 77:15511555 .

Norelli, J.L., H.T. Holleran, W.C. Johnson, T.L. Robinson, and H.S. Aldwinckle. 2003. Resistance of Geneva and other apple rootstocks to Erwinia amylovora. Plant Dis. 87:26-32.

Robinson, T., L. Anderson, W. Autio, B. Barritt, J. Cline, R. Crassweller, W. Cowgill, C. Embree, D. Ferree, E. Garcia, G. Greene, C. Hampson, K. Kosola, M. Parker, R. Perry, T. Roper, and M. Warmund. 2006. A multi-location comparison of Geneva 16, Geneva 41 and M.9 apple rootstocks across North America. Compact Fruit Tree 39:22-23.

Robinson, T.L. 2003. Apple orchard systems. In D.C. Ferree and I.J. Warrington (eds.). Apples: Physiology, production and uses. CABI Publishing, Wallingford, Oxon, UK.

Robinson, T.L., A.M. DeMarree, and S.A. Hoying. 2007. An economic comparison of five high density apple planting systems. Acta Hort. 732:481-490.

Robinson, T.L. and A.N. Lakso. 1991. Bases of yield and production efficiency in apple orchard systems. J. Amer. Soc. Hort. Sci. 116:188-194.

Robinson, T.L., A.N. Lakso, and Z. Ren. 1991. Modifying apple tree canopies for improved production efficiency. HortScience 26:1005-1012.

Schupp, J.R., D.A. Rosenberger, T.L. Robinson, H Aldwinckle, J. Norelli, and P.J. Porpiglia. 2002. Post-symptom sprays of prohexadione-calcium affect fire blight infection of 'Gala' apple on susceptible or resistant rootstocks. HortScience 37:903-905

Travis, J.W., J.L. Rytter, and K.D. Hickey. 1999 The susceptibility of apple rootstocks and cultivars to Erwinia amylovora. Acta Hort. 489:235-241.

Vanneste, J.L. and S. Eden-Greene. 2000. Migration of Erwinia amylovora in host plant tissues. p. 73-87. In J.L. Vanneste (ed.). Fire blight: The disease and its causative agent, Erwinia amylovora. $\mathrm{CAB}$ International, Wallingford, $\mathrm{UK}$.

Webster, T., K. Tobutt, and K. Evans. 2000. Breeding and evaluation of new rootstocks of apple pear and sweet cherry. Compact Fruit Tree 33:100-104.

Westwood, M.N. 1988. Temperate zone pomology. Timber Press, Portland, OR. 